\title{
Role of nonproductive tillers as transient sinks of assimilates in wheat
}

\author{
Samuel Luiz Fioreze ${ }^{1 *}$ (D), Luiz Henrique Michelon ${ }^{1}$ (D), Thaís Lemos Turek² (D), \\ Robson Pelissari Drun ${ }^{1}$ (D), Julio César Sbardella Dalorsaleta ${ }^{1}$ (D) \\ 1 Universidade Federal de Santa Catarina - Departamento de Ciências Biológicas e Agronômicas - Curitibanos (SC), Brazil. \\ 2. Universidade do Estado de Santa Catarina - Centro de Ciências Agroveterinárias - Fisiologia e Manejo de Plantas de \\ Lavoura - Lages (SC), Brazil.
}

\begin{abstract}
Although source-sink relationships in wheat are well studied, the performance of tillers as transient sinks is still unclear, especially under stress conditions. Thus, this work aimed to study the yield relationships of wheat stems in contrasting genotypes as affected by tiller treatment under stress conditions. Two experiments were conducted under greenhouse conditions using BRS Guamirim (high tillering) and BRS Parrudo (low tillering) wheat cultivars. Four tillering treatments were applied on late tillers in the first growing season (2016) and three in the second (2017): (i) free-tillering, (ii) detillering, (iii) physical suppression (only in the first season) and (iv) "spikes removal". The main stem and the first four emitted tillers were considered as primary tillers. Plants were submitted to drought (2016) and defoliation stress (2017) at preanthesis. Intraspecific competition among tillers increased under drought stress conditions and decreased the plant performance. Nonproductive late tillers do not improve the performance of primary tillers of wheat plants under drought stress, mainly in high-tillering cultivars. The reduction on the thousand grain weight of only 'Parrudo' detillered plants indicates that assimilate remobilization from late tillers to primary tillers and main stem seems to be more effective in low-tillering cultivars.
\end{abstract}

Key words: Triticum aestivum, source-sink relationship, tillering, drought stress, defoliation.

\author{
Received: \\ Sep. 18, 2019 \\ Accepted: \\ Feb 3, 2020 \\ Editor: \\ Hector Valenzuela \\ ${ }^{*}$ Correspondence author: \\ s.fioreze@ufsc.br
}

\section{INTRODUCTION}

Comparison among wheat cultivars with contrasting tillering has been addressed under several conditions, such as sowing dates and densities, plant nutrition and environmental stresses (Duggan et al. 2005a, b; Ruan et al. 2012; Mitchell et al. 2013; Guo and Schnurbusch 2015; Hendriks et al. 2016; Houshmandfar et al. 2019). Despite all these studies, it remains difficult to dissect the interactions between main stem and tillers regarding source-sink relationships, mainly under stress conditions. Wheat lines with the Tiller Inhibition (Tin) gene are useful to understand the effects of intraspecific competition and source-sink relationships in wheat plants. However, artificial detillering usually presents more expressive results when compared to Tin plants (Hendriks et al. 2016), enabling the determination of the number and the developmental conditions of emitted tillers.

Wheat plants ability to remobilize assimilated carbon from culm to spike during grain filling has been widely reported, especially under stress or space competition environments, such as drought and defoliation (Mitchell et al. 2013; Guo and Schnurbusch 2015; Turek et al. 2018). However, the mobilization of reserves among tillers of the same plant is less understood. It is well known that during the emergence period, tillers are sustained by the main stem with sugars, water and nutrients, as a result of vascular connections (Alves et al. 2000). However, to act as a transient sink of assimilates, senescent tillers would have to keep these vascular connections with the other stems of the plant (tillers or main stem) until the grain filling stage. 
The use of Tin lines has showed that tiller suppression improves the development and yield potential of the main stem (Mitchell et al. 2013; Hendriks et al. 2016). These favorable effects are showed even under terminal drought (Duggan et al. 2005a). Dreccer et al. (2013) reported that low-tillering wheat genotypes have high concentration of water-soluble carbohydrates in the main culm. This may explain the higher yield potential of individual spikes in these plants (Fioreze et al. 2019). However, the effects of nonproductive tillers on plant performance, mainly under stress, are still not clear.

The artificial manipulation of tillers can be a useful tool to examine source-sink relationships in wheat plants and increase the understanding on yield parameters under stress conditions. Therefore, the objective of this work was to study the yield relationships of wheat culms in contrasting genotypes when affected by tiller management under stress conditions.

\section{MATERIAL AND METHODS}

\section{Experimental design and plant material}

Two experiments (Expt. 1 and 2) were conducted under greenhouse conditions, during the winter of 2016 and 2017 in growing season in the municipality of Curitibanos ( $27^{\circ} 16^{\prime} 26.55^{\prime \prime S}$ latitude and $50^{\circ} 30^{\prime} 14.41^{\prime \prime} \mathrm{W}$ longitude of Greenwich and $988 \mathrm{~m}$ altitude), state of Santa Catarina, Brazil. Greenhouse was adjusted to $25 / 16^{\circ} \mathrm{C}$ day/night thermos period during the experiments. Experiments were carried out in a randomized complete block design with four replications, and arranged as $2 \times 4 \times 2$ (Expt. 1) and $2 \times 3 \times 2$ (Expt. 2) factorial. BRS Guamirim (high tillering) and BRS Parrudo (low tillering) wheat cultivars were used in both experiments as genotypes contrasting for tillering potential (Fioreze et al. 2019). Greenhouse conditions were used to obtain plants with the same number of tillers (and sequence of emergence from the main stem) and reach a good standard of tiller treatment among plants.

Four tillering treatments were applied on late tillers in Expt. 1 and three in Expt. 2 (Fig. 1): (i) free-tillering (control, without pruning of any spikes or tillers), (ii) detillering, (iii) physical suppression (only in 2016) and (iv) "spikes removal". Tillering treatments were applied at stage 31 of the Zadoks scale (Zadoks et al 1974), considered as the first detectable node in the main culm. The main stem and the first four emitted tillers were considered as primary tillers. For 'Guamirim', primary tillers were T0, T1, T1.1 and T2, while for 'Parrudo' these tillers were T1, T1.1, T2 and T3 (Masle 1984). All tillers emitted after these were considered as late tillers. For detillered plants (Fig. 1) all late tillers were manually removed using tweezers. For the physical suppression treatment, late tillers were wrapped in black plastic bags. For spikes removal, only the spikes of late tillers were removed, at the preanthesis stage. The number and dry mass of removed tillers (detillered plants) were determined for characterization.
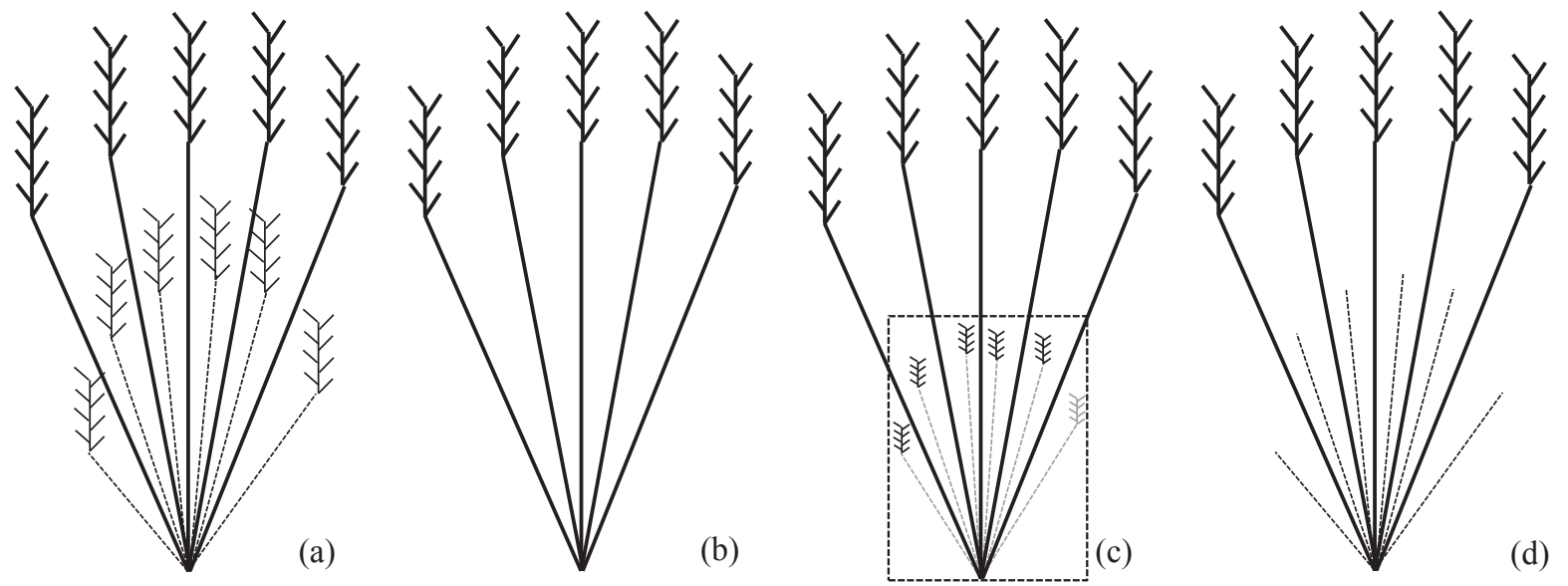

Figure 1. Free-tillering (a) detillering (b), physical suppression (c) and spikes removal (d) plants. Solid lines represent primary tillers. Dashed lines represent late tillers. 
The work aimed to simulate a short-time (drought) and a long-time (defoliation) period of restriction of assimilates availability to better explore the source-sink relationship. Thus, the third experimental factor was the imposition of a stress condition, aiming to limit the source of assimilates in wheat plants. In the first experiment, plants were subjected to drought at the preanthesis stage by irrigation suppression. During drought period, carbon net assimilation $(A)$ was monitored using a portable photosynthesis meter with an opened system IRGA LI-6400xt (Licor, Inc., Lincoln, NE, USA). Measurements were performed in fully expanded flag leaves of main stem, between 9:00 and 11:00 AM. Plants were rehydrated when $A$ values reached zero. In the second experiment, the stress conditions were imposed by total defoliation of the primary tillers at the preanthesis.

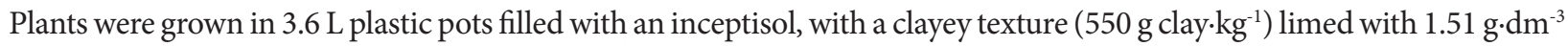
of limestone. Base fertilization was mixed with the soil and consisted of $120 \mathrm{mg} \cdot \mathrm{dm}^{-3}$ of potassium chloride $\left(60 \%\right.$ of $\mathrm{K}_{2} \mathrm{O}$ ) and $2.16 \mathrm{~g} \cdot \mathrm{dm}^{-3}$ of triple superphosphate $\left(42 \%\right.$ of $\left.\mathrm{P}_{2} \mathrm{O}_{5}\right)$. In each pot, four seeds were sown at 3-cm depth. After seedling emergence, thinning was performed, maintaining three plants per pot. Side dressing nitrogen fertilization took place at

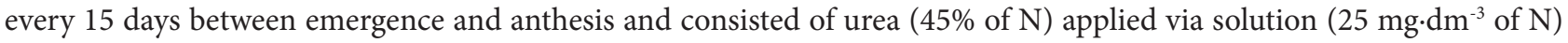
to reach $150 \mathrm{mg} \mathrm{N} \cdot \mathrm{dm}^{-3}$. Soil moisture was maintained close to field capacity throughout the growing period (except for drought treatments) through manual irrigation.

\section{Yield parameters}

At the maturity stage, spikes were harvested to determine yield parameters. Plants were separated into (i) main stem, (ii) primary tillers and (iii) secondary tillers (for free-tillering plants). For Expt. 1, the number of grains and grain weight per spike were determined. For Expt. 2, the thousand grain weight (TGW) and grain weight per spike were determined. With these data, it was possible to evaluate the yield parameters of the main culm, primary tillers (main stem and tillers) and of the whole plant. Additionally, plant yield was determined.

\section{Statistical analysis}

Data was submitted to analysis of variance by the F-test $(\mathrm{p}<0.05)$. Means were compared by the Tukey's test ( $\mathrm{p}<0.05)$, using the SISVAR software (Ferreira 2011). The interaction effect between wheat cultivars and the stresses imposed were evaluated based on the number of tillers and number of productive tillers (free-tillering plants).

\section{RESULTS}

\section{Tiller emission and survival}

The average number of tillers removed (detillering treatment of the Expt. 1) of 'Parrudo' was smaller than that of 'Guamirim', both for irrigated and drought-stressed plants (Table 1). The number of emitted tillers and number of fertile tillers was not affected by stress conditions (Expt. 1 and 2) and not even by cultivars by stress interaction (Table 2). For the two experiments, plants of 'Guamirim' showed higher genetic potential for tiller emission (total and fertile tillers), which agrees with other published data (Fioreze et al. 2019).

Table 1. Number and dry matter of tillers per plant and dry matter per tiller removed (detillered plants of Expt. 1) in two wheat cultivars.

\begin{tabular}{cccc}
\hline Expt. 1 & Number of tillers & Dry matter of tillers $(\mathbf{g})$ & Dry matter per tiller (g) \\
\hline 'BRS Guamirim' & $10.3 \mathrm{a}$ & $2.4 \mathrm{~b}$ & $0.23 \mathrm{~b}$ \\
\hline 'BRS Parrudo' & $4.0 \mathrm{~b}$ & $2.8 \mathrm{a}$ & $0.69 \mathrm{a}$ \\
\hline
\end{tabular}

Means followed by the same letter do not differ by the Tukey's test $(p<0.05)$. 


\section{Physiological and yield parameters of wheat plants under drought stress}

The carbon net assimilation $(A)$ determination was used to evaluate drought stress effects on wheat plants (Fig. 2) in the Expt. 1. For 'Guamirim', $A$ values in free-tillering and "spikes removal" plants reached values near zero at nine days after irrigation suppression (Fig. 2 a). Detillered plants, as well as plants with physical tiller suppression showed $A$ values near zero six days after the other treatments (15 days after irrigation suppression). A similar result was observed for 'Parrudo', although detillered plants and plants with physical tiller suppression reached $A$ values near zero two days after the other group (Fig. 2 b).

Drought stress did not affect the number of grains per spike in the Expt. 1 (Table 3). However, the number of grains per spike showed a significant interaction between wheat cultivars and tiller treatment. For all forms of evaluation (main stem, primary tillers and whole plant), 'Parrudo' showed higher number of grains per spike (Table 4). In 'Guamirim', higher number of grains per spike was observed in detillered plants. In addition, when mean of all spikes of the plants is considered (whole plant), all tiller-managed plants showed higher number of grains per spike than free-tillering plants. Except for main stem, both tiller removal and even physical suppression, increased the number of grains per spike in 'Parrudo' plants.

Grain weight per spike and per plant showed interaction between the three factors studied in the Expt. 1 (Table 3). Grain weight per spike of primary tillers was higher in irrigated plants of both cultivars (Table 5). Both for irrigated and drought conditions, primary tillers of 'Parrudo' were more productive. Average grain weight of all spikes of the plant (whole

Table 2. Number of tillers per plant (NT) and number of viable tillers per plant (NVT) in two wheat cultivars as affected by drought (Expt. 1) or defoliation stress (Expt. 2).

\begin{tabular}{|c|c|c|c|c|c|}
\hline Expt. 1 & NT & NVT & Expt. 2 & NT & NVT \\
\hline Control & 15.63 & 14.51 & Control & 12.25 & 11.50 \\
\hline Drought stress & 16.63 & 15.13 & Defoliation & 13.75 & 12.75 \\
\hline$p$ & 0.21 & 0.36 & $p$ & 0.09 & 0.17 \\
\hline 'BRS Guamirim' & $21.50 \mathrm{a}$ & $20.38 a$ & 'BRS Guamirim' & $16.50 \mathrm{a}$ & $15.75 a$ \\
\hline 'BRS Parrudo' & $10.75 b$ & $9.25 b$ & 'BRS Parrudo’ & $9.50 \mathrm{~b}$ & $8.50 \mathrm{~b}$ \\
\hline$p$ & 0.00 & 0.00 & $p$ & 0.00 & 0.00 \\
\hline$D S \times C(p)$ & 0.07 & 0.12 & $D \times C(p)$ & 0.24 & 0.39 \\
\hline CV (\%) & 9.30 & 8.88 & CV (\%) & 12.16 & 13.68 \\
\hline
\end{tabular}

p: probability of F test; CV: coefficient of variation. Means followed by the same letter do not differ by the Tukey's test ( $p<0.05)$; DS: drought stress; C: cultivars; TM: tiller treatment; D: defoliation.
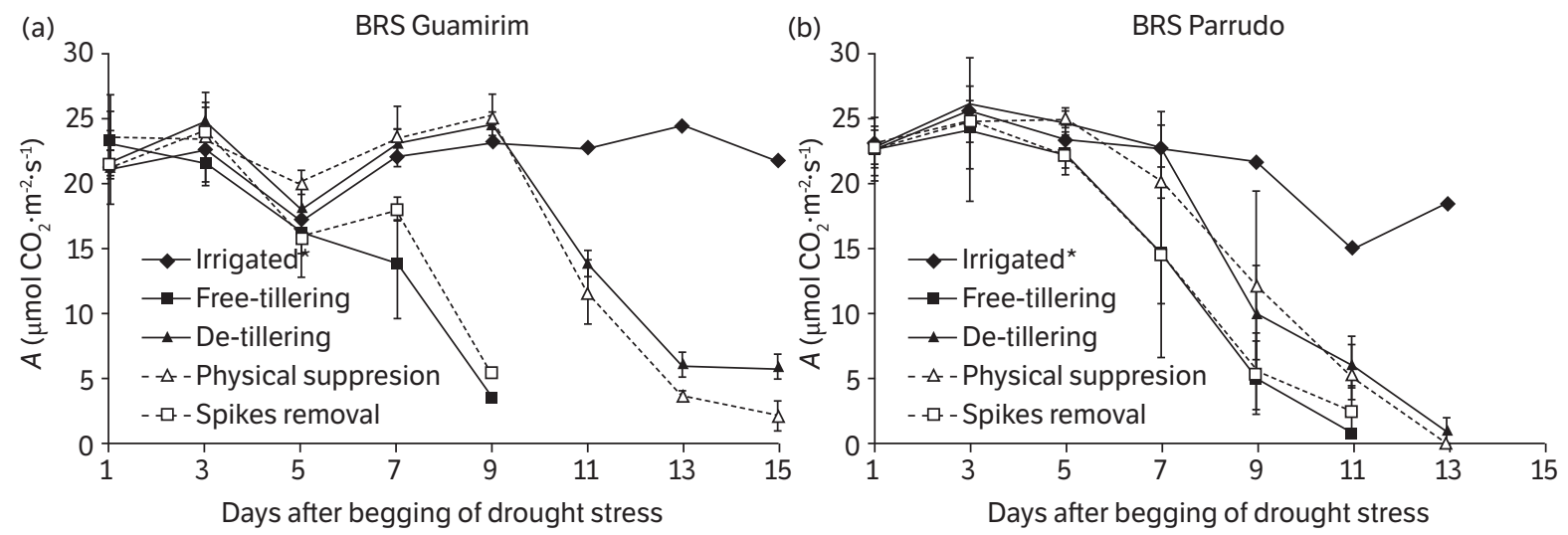

Figure 2. Carbon net assimilation of 'BRS Guamirim' (A) and 'BRS Parrudo' (B) plants as affected by drought stress at preanthesis stage (Expt. 1). Vertical bars indicate standard deviation. 
Table 3. Number of grains per spike and grain yield in wheat cultivars as affected by tiller treatment and drought stress (Expt. 1).

\begin{tabular}{|c|c|c|c|c|c|c|c|}
\hline & \multicolumn{3}{|c|}{ Grains per spike } & \multicolumn{4}{|c|}{ Grain yield (g) } \\
\hline & MS & $\mathrm{PT}^{1}$ & $W P^{2}$ & MS & $\mathrm{PT}^{1}$ & $W^{2}$ & $\mathrm{PY}^{3}$ \\
\hline Irrigated & 66.5 & 59.4 & 56.7 & 3.11 & 2.75 & 2.62 & 16.96 \\
\hline Drought stress & 67.0 & 59.2 & 56.2 & 3.02 & 2.67 & 2.53 & 16.13 \\
\hline$p$ & 0.80 & 0.83 & 0.70 & 0.27 & 0.11 & 0.12 & 0.00 \\
\hline ‘BRS Guamirim’ & 53.5 & 45.1 & 41.4 & 2.58 & 2.22 & 2.04 & 14.95 \\
\hline 'BRS Parrudo' & 80.0 & 73.5 & 71.6 & 3.55 & 3.19 & 3.11 & 18.15 \\
\hline$p$ & 0.00 & 0.00 & 0.00 & 0.00 & 0.00 & 0.00 & 0.00 \\
\hline Free-tillering & 65.9 & 57.9 & 46.6 & 2.86 & 2.44 & 1.90 & 24.19 \\
\hline Detillering & 71.0 & 63.7 & 63.7 & 3.23 & 2.94 & 2.94 & 14.70 \\
\hline Physical Suppression & 66.0 & 59.2 & 59.2 & 2.95 & 2.65 & 2.65 & 13.23 \\
\hline Spikes removal & 64.1 & 56.3 & 56.3 & 3.22 & 2.82 & 2.82 & 14.07 \\
\hline$p$ & 0.04 & 0.00 & 0.00 & 0.00 & 0.00 & 0.00 & 0.00 \\
\hline$D S \times C(p)$ & 0.49 & 0.81 & 0.94 & 0.08 & 0.02 & 0.04 & 0.00 \\
\hline$D S \times T T(p)$ & 0.03 & 0.25 & 0.26 & 0.23 & 0.51 & 0.54 & 0.01 \\
\hline$C \times T T(p)$ & 0.03 & 0.00 & 0.00 & 0.00 & 0.00 & 0.00 & 0.00 \\
\hline$D S \times C \times T T(p)$ & 0.29 & 0.11 & 0.15 & 0.13 & 0.27 & 0.35 & 0.08 \\
\hline CV (\%) & 10.24 & 7.61 & 8.38 & 9.64 & 7.69 & 8.74 & 6.99 \\
\hline
\end{tabular}

MS: main stem; $\mathrm{PT}^{1}$ : primary tillers (main stem + primary tillers); WP2: whole plant; PY³: plant yield; Only free-tillering plants show productive late tillers, values of $\mathrm{PP}^{1}$ e WP ${ }^{2}$ are the same for other treatments; $p$ : probability of $\mathrm{F}$ test; $\mathrm{CV}$ : coefficient of variation. Means followed by the same letter do not differ by the Tukey's test $(p<0.05)$; DS: drought stress; C: cultivars; TT: tiller treatment.

Table 4. The effect of "tiller treatment $\times$ cultivar" interaction on number of grains per spike in wheat plants (Expt. 1).

\begin{tabular}{ccccccc}
\hline & \multicolumn{2}{c}{ Main stem } & \multicolumn{2}{c}{ Primary tillers ${ }^{1}$} & \multicolumn{2}{c}{ Whole plant } \\
\cline { 2 - 6 } & 'BRS Guamirim' & 'BRS Parrudo' & 'BRS Guamirim' & 'BRS Parrudo' & 'BRS Guamirim' & 'BRS Parrudo' \\
\hline Free-tillering & $52.6 \mathrm{Bb}$ & $79.1 \mathrm{Aa}$ & $44.2 \mathrm{Bb}$ & $71.6 \mathrm{Ab}$ & $29.2 \mathrm{Bc}$ & $64.1 \mathrm{Ac}$ \\
\hline Detillering & $61.9 \mathrm{Ba}$ & $80.1 \mathrm{Aa}$ & $52.3 \mathrm{Ba}$ & $75.3 \mathrm{Aab}$ & $52.2 \mathrm{Ba}$ & $75.3 \mathrm{Aab}$ \\
\hline Physical Suppression & $49.5 \mathrm{Bb}$ & $82.5 \mathrm{Aa}$ & $41.5 \mathrm{Bb}$ & $77.0 \mathrm{Aa}$ & $41.5 \mathrm{Bb}$ & $76.0 \mathrm{Aa}$ \\
\hline Spikes removal & $50.0 \mathrm{Bb}$ & $78.3 \mathrm{Aa}$ & $42.6 \mathrm{Bb}$ & $70.0 \mathrm{Ab}$ & $42.6 \mathrm{Bb}$ & $70.0 \mathrm{Abc}$ \\
\hline
\end{tabular}

Uppercase letters refer to cultivars, lowercase letters compare tiller treatment by Tukey’s test $(p<0.05)$. Primary tillers ${ }^{1}$ : Main stem and primary tillers.

plant) and plant yield were not affected by drought stress in 'Parrudo', while this condition reduced 'Guamirim' yield. Only free-tillering plants reduced grain yield under drought conditions, probably as an effect of loss of yield potential in late tillers in a limiting environment. As expected, free-tillering plants showed higher grain yield for both environments, as an effect of the larger number of spikes. Both for irrigated and drought conditions, plants submitted to late tiller treatment differed little or not at all.

Grain weight of main stem, primary tillers and average of whole plant was higher for 'Parrudo' for all tiller treatment (Table 5). In terms of individual yield of spikes, detillering increased grain weight of 'Guamirim' plants. In 'Parrudo' plants, highest grain weight of main stem was observed when only spikes of late tillers were removed. Grain weight of primary tillers and average of whole plant of 'Parrudo' were increased by tiller treatment.

'Parrudo' was more productive than 'Guamirim', except for free-tillering plants, where 'Guamirim' was better (Table 5). As expected, plant yield was highest in free-tillering plants of two wheat cultivars. For three forms of tiller treatment, the tiller removal improved grain yield in 'Guamirim' plants. For 'Parrudo', they did not differ from each other. 
Table 5. Effect of "drought stress $\times$ cultivar", "drought stress $\times$ tiller treatment" and "tiller treatment $\times$ cultivar" interaction on grain weight per spike and per plant (grain yield) of wheat (Expt. 1).

\begin{tabular}{|c|c|c|c|c|c|c|}
\hline & \multicolumn{2}{|c|}{ Primary tillers $^{1}(\mathrm{~g})$} & \multicolumn{2}{|c|}{ Whole plant (g) } & \multicolumn{2}{|c|}{ Plant yield (g) } \\
\hline & Irrigated & Drought stress & Irrigated & Drought stress & Irrigated & Drought stress \\
\hline 'BRS Guamirim’ & $2.19 \mathrm{Ab}$ & $2.24 \mathrm{Bb}$ & $2.03 \mathrm{Ab}$ & $2.06 \mathrm{Ab}$ & $14,92 \mathrm{Ab}$ & $14,98 \mathrm{Ab}$ \\
\hline \multirow[t]{3}{*}{ 'BRS Parrudo' } & $3.31 \mathrm{Aa}$ & $3.09 \mathrm{Ba}$ & $3.21 \mathrm{Aa}$ & $3.01 \mathrm{Ba}$ & $19,00 \mathrm{Aa}$ & $17,29 \mathrm{Ba}$ \\
\hline & \multicolumn{6}{|c|}{ Plant yield (g) } \\
\hline & \multicolumn{3}{|c|}{ Irrigated } & \multicolumn{3}{|c|}{ Drought stress } \\
\hline Free-tillering & \multicolumn{3}{|c|}{$25.44 \mathrm{Aa}$} & \multicolumn{3}{|c|}{$22.94 \mathrm{Ba}$} \\
\hline Detillering & \multicolumn{3}{|c|}{$14.60 \mathrm{Ab}$} & \multicolumn{3}{|c|}{$14.79 \mathrm{Ab}$} \\
\hline Physical Suppression & \multicolumn{3}{|c|}{$13.47 \mathrm{Ab}$} & \multicolumn{3}{|c|}{$12.98 \mathrm{Ac}$} \\
\hline \multirow[t]{3}{*}{ Spikes removal } & \multicolumn{3}{|c|}{$14.33 \mathrm{Ab}$} & \multicolumn{3}{|c|}{$13.82 \mathrm{Abc}$} \\
\hline & \multicolumn{3}{|c|}{ Main stem (g) } & \multicolumn{3}{|c|}{ Primary tillers ${ }^{1}(g)$} \\
\hline & BRS Guamirim & BRS P & Ido & BRS G & irim & BRS Parrudo \\
\hline Free-tillering & $2.49 \mathrm{Bb}$ & 3.2 & & 2.0 & & $2.83 \mathrm{Ab}$ \\
\hline Detillering & $2.92 \mathrm{Ba}$ & 3.5 & & & & $3.24 \mathrm{Aa}$ \\
\hline Physical Suppression & $2.41 \mathrm{Bb}$ & 3.4 & & 2.0 & & $3.25 \mathrm{Aa}$ \\
\hline \multirow[t]{3}{*}{ Spikes removal } & $2.50 \mathrm{Bb}$ & 3.9 & & & & $3.47 \mathrm{Aa}$ \\
\hline & \multicolumn{3}{|c|}{ Whole plant (g) } & \multicolumn{3}{|c|}{ Plant yield (g) } \\
\hline & 'BRS Guamirim' & 'BRS P & Ido' & 'BRS G & irim' & 'BRS Parrudo' \\
\hline Free-tillering & $1.33 \mathrm{Bc}$ & 2.4 & & 25. & & $22.79 \mathrm{Ba}$ \\
\hline Detillering & $2.64 \mathrm{Ba}$ & 3.2 & & 13.1 & & $16.21 \mathrm{Ab}$ \\
\hline Physical Suppression & $2.04 \mathrm{Bb}$ & 3.2 & & 10. & & $16.26 \mathrm{Ab}$ \\
\hline Spikes removal & $2.16 \mathrm{Bb}$ & 3.4 & & 10. & & $17.33 \mathrm{Ab}$ \\
\hline
\end{tabular}

Uppercase letters refer to drought stress or cultivars, lowercase letters compare tiller treatment by Tukey's test $(p<0.05)$. Primary tillers ${ }^{1}$ : Main stem and primary tillers.

\section{Yield parameters of wheat plants under defoliation}

The TGW was drastically reduced by defoliation in the Expt. 2 (Table 6). For primary tillers as well as the whole plant, higher TGW was obtained for 'Guamirim'. For the same data, plants where only the spikes of late tillers were removed (spikes removal) showed higher TGW than other treatments. The TGW of main stem was affected by interaction between cultivars and tiller treatment (Table 6). Wheat cultivars did not differ for TGW of main stem in free-tillering plants (Table 7). However, 'Guamirim' was higher than 'Parrudo' for detillered and 'spikes removal' plants. Main stem of detillered and 'spikes removal' plants of 'Guamirim' had higher TGW than free-tillering plants. For 'Parrudo', only "spikes removal” of late tillers increased the TGW of main culm.

Grain weight per spike and per plant was affected by significant interaction between the factors of study in the Expt. 2 (double interactions) (Table 6). When not defoliated, 'Parrudo' had greater values than 'Guamirim' in terms of main stem, primary tillers and whole plant (Table 8). Under defoliation, 'Parrudo' was higher only for grain yield of primary tillers and on average of all spikes (whole plant). Grain weight of main stem and plant yield didn’t differ among cultivars.

Regardless of tiller treatment, the grain weight per spike and per plant was reduced under defoliation (Table 8). When not defoliated, grain weight of main stem, primary tillers and on average of all spikes were higher in detillered plants. Under defoliation, spikes of detillered plants were more productive, but did not differ from "spikes removal" plants. 
Table 6. Thousand grain weight, grain weight per spike and per plant (grain yield) in wheat cultivars as affected by defoliation stress and tiller treatment (Expt. 2).

\begin{tabular}{cccccccc}
\hline & \multicolumn{2}{c}{ Thousand grain weight $(\mathrm{g})$} & & \multicolumn{2}{c}{ Grain Yield (g) } \\
\cline { 2 - 7 } & $\mathrm{MS}$ & $\mathrm{PT}^{1}$ & $\mathrm{WP}^{2}$ & $\mathrm{MS}$ & $\mathrm{PT}^{1}$ & WP $^{2}$ & $\mathrm{PY}^{3}$ \\
\hline Control & $43.2 \mathrm{a}$ & $42.0 \mathrm{a}$ & $44.9 \mathrm{a}$ & 2.87 & 2.48 & 2.34 & 14.53 \\
\hline Defoliation & $34.2 \mathrm{~b}$ & $33.9 \mathrm{~b}$ & $35.9 \mathrm{~b}$ & 2.11 & 1.84 & 1.75 & 11.42 \\
\hline$p$ & 0.00 & 0.00 & 0.00 & 0.00 & 0.00 & 0.00 & 0.00 \\
\hline 'BRS Guamirim' & 41.6 & $40.2 \mathrm{a}$ & $42.7 \mathrm{a}$ & 2.29 & 1.94 & 1.76 & 12.31 \\
\hline 'BRS Parrudo' & 35.8 & $35.7 \mathrm{~b}$ & $38.1 \mathrm{~b}$ & 2.69 & 2.39 & 2.32 & 13.64 \\
\hline$p$ & 0.00 & 0.00 & 0.01 & 0.00 & 0.00 & 0.00 & 0.00 \\
\hline Free-tillering & 34.9 & $33.7 \mathrm{c}$ & $41.0 \mathrm{ab}$ & 2.07 & 1.77 & 1.41 & 15.49 \\
\hline Detillering & 37.9 & $37.5 \mathrm{~b}$ & $37.5 \mathrm{~b}$ & 2.65 & 2.40 & 2.40 & 12.00 \\
\hline Spikes removal & 43.3 & $42.6 \mathrm{a}$ & $42.6 \mathrm{a}$ & 2.75 & 2.31 & 2.31 & 11.44 \\
\hline$p$ & 0.00 & 0.00 & 0.03 & 0.00 & 0.00 & 0.00 & 0.00 \\
\hline$D \times C(p)$ & 0.13 & 0.14 & 0.38 & 0.00 & 0.00 & 0.01 & 0.03 \\
\hline$D \times T T(p)$ & 0.09 & 0.08 & 0.46 & 0.02 & 0.01 & 0.00 & 0.05 \\
\hline$C \times T T(p)$ & 0.02 & 0.11 & 0.31 & 0.02 & 0.00 & 0.00 & 0.00 \\
\hline$D \times C \times T T(p)$ & 0.02 & 0.07 & 0.19 & 0.36 & 0.81 & 0.94 & 0.93 \\
\hline$C V(\%)$ & 10.36 & 10.72 & 13.34 & 11.58 & 8.97 & 9.82 & 10.8 \\
\hline
\end{tabular}

MS: main stem; $\mathrm{PT}^{1}$ : MS and primary tillers; WP ${ }^{2}$ : whole plant. PY3: plant yield; Only free-tillering plants show productive late tillers, values of $\mathrm{PT}^{1}$ e $\mathrm{WP}^{2}$ are the same for other treatments; $p$ : probability of F test; $C V$ : coefficient of variation. Means followed by the same letter do not differ by the Tukey's test ( $p<0.05$ ); $D$ : defoliation stress; C: cultivars; TT: Tiller treatment.

Table 7. The effect of "tiller treatment $\times$ cultivar" interaction on thousand grain weight of wheat main stem (Expt. 2).

\begin{tabular}{ccc}
\hline & 'BRS Guamirim’ & 'BRS Parrudo’ \\
\hline Free-tillering & $35.6 \mathrm{Ab}$ & $34.2 \mathrm{Ab}$ \\
\hline Detillering & $42.8 \mathrm{Aa}$ & $33.0 \mathrm{Bb}$ \\
\hline Spikes removal & $46.4 \mathrm{Aa}$ & $40.1 \mathrm{Ba}$ \\
\hline
\end{tabular}

Uppercase letters refer to cultivars, lowercase letters compare tiller treatment by Tukey's test $(p<0.05)$.

Defoliation drastically reduced plant yield, regardless of tiller treatment (Table 8). As free-tillering plants emitted more spikes than the others, this treatment was more productive in defoliated and nondefoliated plants. However, plants subjected to removal of late tillers or even the spike removal of late tillers were more affected.

Grain weight per spike (main culm, primary tillers and whole plant) was higher in detillered and in "spikes removal" plants of both wheat cultivars (Table 8). With the exception of detillered plants, the grain number per spike was higher in 'Parrudo' than 'Guamirim'. In general, grain yield of individual spikes was increased by tiller removal or even by "spikes removal" of late tillers. For 'Guamirim', however, detillered plants were higher than others treatments.

With exception to "spikes removal" plants, there were no differences in plant yield among wheat cultivars (Table 8). As observed in the Expt. 1, higher plant yield was obtained in free-tillering plants of both cultivars. For 'Guamirim', intermediate plant yield was observed in detillered plants, while "spikes removal" plants were lower. For 'Parrudo' these treatments did not differ. 
Table 8. Effect of "defoliation $\times$ cultivar", "defoliation $\times$ tiller treatment" and "tiller treatment $\times$ cultivar" interaction on grain weight per spike and per plant (grain yield) of wheat (Expt. 2).

\begin{tabular}{|c|c|c|c|c|}
\hline & \multicolumn{2}{|c|}{ Main stem (g) } & \multicolumn{2}{|c|}{ Primary tillers $^{1}(\mathrm{~g})$} \\
\hline & Control & Defoliation & Control & Defoliation \\
\hline ‘BRS Guamirim’ & $2.51 \mathrm{Ab}$ & $2.07 \mathrm{Ba}$ & $2.15 \mathrm{Ab}$ & $1.72 \mathrm{Bb}$ \\
\hline \multirow[t]{3}{*}{ 'BRS Parrudo' } & $3.23 \mathrm{Aa}$ & $2.15 \mathrm{Ba}$ & $2.80 \mathrm{Aa}$ & $1.97 \mathrm{Ba}$ \\
\hline & \multicolumn{2}{|c|}{ Whole plant (g) } & \multicolumn{2}{|c|}{ Plant yield (g) } \\
\hline & Control & Defoliation & Control & Defoliation \\
\hline ‘BRS Guamirim’ & $1.98 \mathrm{Ab}$ & $1.55 \mathrm{Bb}$ & $13.39 \mathrm{Ab}$ & $11.23 \mathrm{Ba}$ \\
\hline \multirow[t]{3}{*}{ 'BRS Parrudo' } & $2.69 \mathrm{Aa}$ & $1.95 \mathrm{Ba}$ & $16.67 \mathrm{Aa}$ & $11.61 \mathrm{Ba}$ \\
\hline & \multicolumn{2}{|c|}{ Main stem (g) } & \multicolumn{2}{|c|}{ Primary tillers ${ }^{1}(\mathrm{~g})$} \\
\hline & Control & Defoliation & Control & Defoliation \\
\hline Free-tillering & $2.45 \mathrm{Ab}$ & $1.69 \mathrm{Bc}$ & $2.01 \mathrm{Ac}$ & $1.53 \mathrm{Bb}$ \\
\hline Detillering & $3.18 \mathrm{Aa}$ & $2.13 \mathrm{Bb}$ & $2.86 \mathrm{Aa}$ & $1.94 \mathrm{Ba}$ \\
\hline \multirow[t]{3}{*}{ Spikes removal } & $2.98 \mathrm{Aa}$ & $2.52 \mathrm{Ba}$ & $2.56 \mathrm{Ab}$ & $2.06 \mathrm{Ba}$ \\
\hline & \multicolumn{2}{|c|}{ Whole plant (g) } & \multicolumn{2}{|c|}{ Plant yield (g) } \\
\hline & Control & Defoliation & Control & Defoliation \\
\hline Free-tillering & $1.59 \mathrm{Ac}$ & $1.24 \mathrm{Bb}$ & 16.74 Aa & 14.24 Ba \\
\hline Detillering & $2.86 \mathrm{Aa}$ & $1.94 \mathrm{Ba}$ & $14.28 \mathrm{Ab}$ & $9.72 \mathrm{Bb}$ \\
\hline \multirow[t]{3}{*}{ Spikes removal } & $2.56 \mathrm{Ab}$ & $2.06 \mathrm{Ba}$ & $12.58 \mathrm{Ab}$ & $10.31 \mathrm{Bb}$ \\
\hline & \multicolumn{2}{|c|}{ Main stem (g) } & \multicolumn{2}{|c|}{ Primary tillers ${ }^{1}(\mathrm{~g})$} \\
\hline & 'BRS Guamirim’ & 'BRS Parrudo' & ‘BRS Guamirim’ & 'BRS Parrudo' \\
\hline Free-tillering & $1.85 \mathrm{Bb}$ & $2.29 \mathrm{Ac}$ & $1.53 \mathrm{Bc}$ & $2.00 \mathrm{Ab}$ \\
\hline Detillering & $2.61 \mathrm{Aa}$ & $2.69 \mathrm{Ab}$ & $2.34 \mathrm{Aa}$ & $2.46 \mathrm{Aa}$ \\
\hline \multirow[t]{3}{*}{ Spikes removal } & $2.41 \mathrm{Ba}$ & $3.09 \mathrm{Aa}$ & $1.93 \mathrm{Bb}$ & $2.69 \mathrm{Aa}$ \\
\hline & \multicolumn{2}{|c|}{ Whole plant (g) } & \multicolumn{2}{|c|}{ Plant yield (g) } \\
\hline & 'BRS Guamirim’ & 'BRS Parrudo' & 'BRS Guamirim' & 'BRS Parrudo' \\
\hline Free-tillering & $1.02 \mathrm{Bc}$ & $1.81 \mathrm{Ab}$ & $15.82 \mathrm{Aa}$ & 15.16 Aa \\
\hline Detillering & $2.34 \mathrm{Aa}$ & $2.46 \mathrm{Aa}$ & $11.70 \mathrm{Ab}$ & $12.29 \mathrm{Ab}$ \\
\hline Spikes removal & $1.93 \mathrm{Bb}$ & $2.69 \mathrm{Aa}$ & $9.75 \mathrm{Bc}$ & 13.46 Aab \\
\hline
\end{tabular}

Uppercase letters refer to defoliation stress or cultivars (lines), lowercase letters compare cultivars or tiller treatment (column) by Tukey's test ( $p<0.05)$. Primary tillers ${ }^{1}$ : Main stem and primary tillers.

\section{DISCUSSION}

\section{Effect of cultivar and stress on source-sink relationships}

Striking differences were observed for tiller emission and dry mater accumulation among wheat cultivars for both experiments (Tables 1 and 2). Lower tillered plants, such as 'Parrudo', produce tillers with a larger stem diameter and longer leaves (Gross et al. 2012), which results in higher yield potential (Fioreze et al. 2019).

Defoliation is an important tool to study source-sink relationships in wheat plants because it allows measuring the effects of remobilization of preanthesis carbohydrates (Shao et al. 2010). Drought stress, however, interacts in several ways with the plants, affecting photosynthesis, translocation of water and solutes and plant growth. These effects are increased according to intraspecific competition. Despite the detrimental effects of the two forms of stress, it is interesting to point out that none of them affected the number of tillers per plant, mainly in terms of fertile tillers (Table 2). 
Although environmental stress did not affect the number of tillers per plant, free-tillering and 'spikes removal' plants showed an early reduction of carbon net assimilation $(A)$ under drought stress (Expt. 1). High tiller emission (Table 2) results in more leaves and, consequently, higher water consumption. This may explain the differences between cultivars and the effects of tiller removal or physical suppression, mainly in 'Guamirim' plants. The relationship between leaf area and water loss (leaf transpiration) is well known in wheat plants (Thapa et al. 2017; Turek et al. 2018). Hendriks et al. (2016) showed that wheat plants carrying the Tin gene showed lower water consumption during a drought stress period under field conditions and that these plants also had longer root systems. Free-tillering plants of 'Parrudo' kept the higher values of $A$ during a longer period than 'Guamirim' (Expt. 1). Considering that grain yield (in free-tillering plants) varied little between cultivars, (Expt. 1 and 2), it is evident that low-tillering plants are more effective in stressed environments.

The authors of this work hypothesized that reserve mobilization among culms from the same plant would occur in conditions where the source of assimilates was limited. Thus, a reduction on tiller number was expected as an effect of senescence of infertile tillers, especially under drought stress. However, this was not observed. This result allows hypothesizing that, under field drought stress conditions, late tiller senescence is a result of the competition for water (as well as nutrients and radiation) with the whole plant or neighboring plants and not due to a reserve mobilization process. Thus, the occurrence of infertile late tillers increases the competition for a restricted amount of water, reducing the whole plant performance.

\section{Effect of tiller treatment on source-sink relationships}

It was observed that treatment of late tillers increased the yield potential of individual spikes, mainly with respect to the number and grains (Expt. 1). This result demonstrates a clear effect of competition among culms of a plant. The yield potential of spikes is gradually reduced according to phenological delay in late tillers (Fioreze and Rodrigues 2012; Fioreze et al. 2019). This effect applies to the observed differences between wheat cultivars and also to the effect of late tiller removal.

The results of this research were obtained in greenhouse conditions, with only one plant cultivated per pot. On this way, it is important to highlight that low-tillering plants (as an effect of cultivar or even tiller treatment) had greater water and nutrients availability than high-tillering plants. In field conditions, however, low-tillering potential genotypes (as 'Parrudo') will also benefit from the water and nutrients availability. Tin plants were able to better explore the soil in depth and maintain the yield potential under drought stress in field conditions (Hendriks et al. 2016).

The reduction on intraspecific competition, by detillering treatment seems to increase reserve (carbohydrates and nutrients) accumulation in the remaining stems, which increase the spike fertility. The relationship between the availability of assimilated carbon in preanthesis and grain yield is well known in wheat (Inoue et al. 2004; Duggan et al. 2005 b; Mitchell et al. 2013; Guo and Schnurbusch 2015). This argument becomes explicit when the effect of tiller removal on 'Guamirim' (high-tillering potential) as well as in plants under defoliation is observed.

The decrease of competition between wheat tillers was demonstrated in near isogenic lines of plants with the Tin gene under drought stress (Houshmandfar et al. 2019) and saline stress conditions (Ruan et al. 2012). This seems to be an effect of the increase in the amount of water-soluble carbohydrates (WSC) in the stem of plants with this characteristic (Duggan et al. 2015 b). Mitchell et al. (2013) observed higher number and mass of grains per spike in wheat plants with Tin gene under drought stress, which was associated with higher WSC in culms until anthesis. Tiller removal delay a flower deterioration and improves spikelet fertility (Guo and Schnurbusch 2015), probably as an effect of higher WSC in culms.

Dreccer et al. (2013) hypothesized that high WSC concentration in the main stem of wheat plants acts on tiller emission control. However, results of this work indicate that the increase on WSC in wheat culms is an effect of the reduction in the number of tillers, not the cause. A rapid elongation of the main stem and acquisition of solid basal stem appear to be a greater determinant for inhibition of tiller emission (Kebrom et al. 2012).

Two aspects are important to consider based on production data in the present study. First, similar values of grain yield (Expt. 1 and 2) can be obtained with a varied number of spikes (Table 2). Second, as tillering potential increases, the effect of intraspecific competition becomes more pronounced. This can be observed by comparing $A$ values between cultivars or even between tiller treatments under drought stress (Expt. 1). 
The values of grain number per spike and thousand grain weight revealed important aspects of source-sink relationships in wheat plants. The number of grains (Expt. 1) was increased by tiller removal, which indicates a beneficial effect on reduction of competition among sinks of assimilates, regardless of environmental condition. Increase on thousand grain weight in detillered and Tin plants is well known (Duggan et al. 2005 a; Mitchell et al. 2013; Hendriks et al. 2016). It was surprising, however, that an increase on thousand grain weight (Expt. 2) occurred in "spikes removal" plants of 'Parrudo' (Table 7). A key point of this research was to determine if nonproductive tillers could participate of grain filling of productive tillers. At least in 'Parrudo' plants, tillers of "spikes removal" plants seem to have participated in the grain filling of the other spikes, increasing the TGW. For it to occur, however, it would be necessary to have an active vascular connection between the stems of the plant.

The increase on grain number is an effect of carbohydrate availability during anthesis, while grain weight is a result of a combination between the filling rate and filling period duration. Both traits directly affect the plant yield (Vesohoski et al. 2011). Variation in number and mass of grains can explain the absence of differences between detillering and "spikes removal", at least for 'Parrudo' (Expt. 1 and 2). Different from what would be expected, the potential of assimilates remobilization between wheat culms can be decreased as the number of tillers increased. During the period between the emission and development of the first leaves, tillers are maintained by the main stem, through vascular connections between them (Alves et al. 2000). The presence of these connections at later stages of the crop cycle, however, has not yet been demonstrated. Such study could improve the understanding of the potential for redistribution of reserves in wheat plants.

Detillered and "spikes removal" plants resulted in decreased grain yields under defoliation (Expt. 2). This result may indicate that an increase on yield potential of individual spikes (number of spikelets and grains per spike) could result in plants that are more sensitive to defoliation. This perspective could change the source-sink relationship of wheat plants, which is known for its tolerance to defoliation (Turek et al. 2018) and high potential for redistribution of reserves from culm to spikes (Inoue et al. 2004; Duggan et al. 2005b; Mitchell et al. 2013; Guo and Schnurbusch 2015; Turek et al. 2018), mainly in the absence of drought stress.

The results from this study bring a new view on the source-sink relationship in wheat stems. These results indicate that the role of late tillers (fertile or not) as transient sinks seems to vary as a function of the plant's tillering potential. Additionally, considering that late tillers (mainly infertile tillers) show low or null redistribution of reserves, emission of these structures could represent an unnecessary energy consumption by the plant, which clearly reduces the productive potential of its other spikes. In addition to the competition for assimilates, tillers compete for water, nutrients and light, which may further reduce the plant yield potential under stress conditions. Finally, late tiller senescence in high-tillering cultivars, under stress conditions, could be an effect of competition with the whole plant, and not of redistribution of reserves.

\section{CONCLUSION}

High number of tillers reduces the performance of wheat plants under drought stress. Nonproductive late tillers do not improve the performance of primary tillers of wheat plants under drought stress, mainly in high-tillering cultivars. Assimilates remobilization from late tillers to primary tillers can be a function of tillering potential.

\section{AUTHORS' CONTRIBUTION}

Conceptualization, Fioreze S. L., Michelon L. H. and Turek, T. L.; Methodology, Fioreze S. L. and Michelon L. H.; Investigation, Michelon L. H., Turek, T. L., Drun R. P. and Dalorsaleta J. C. S.; Writing - Original Draft, Fioreze S. L., Michelon L. H. and Drun R. P.; Writing - Review and Editing, Fioreze S. L. and Michelon L. H.; Supervision, Fioreze S. L. 


\section{REFERENCES}

Alves, A. C, Mundstock, C. M. and Medeiros, J. D. (2000). Sistema vascular e controle do desenvolvimento de perfilhos em cereais de estação fria. Revista Brasileira de Botânica, 23, 59-67. https://doi.org/10.1590/S0100-84042000000100007

Dreccer, M. F., Chapman, S. C., Rattey, A. R., Neal, J., Song, Y., Christopher, J. T. and Reynolds, M. (2013). Developmental and growth controls of tillering and water-soluble carbohydrate accumulation in contrasting wheat (Triticum aestivum L.) genotypes: can we dissect them? Journal of Experimental Botany, 64, 143-160. https://doi.org/10.1093/jxb/ers317

Duggan, B. L., Richards, R. A., Van Herwaarden, A. F. and Fettell, N. A. (2005 a). Agronomic evaluation of a tiller inhibition gene (tin) in wheat. I. Effect on yield, yield components, and grain protein. Australian Journal of Agriculture Research, 56, 169-178. https://doi. org/10.1071/AR04152

Duggan, B. L., Richards, R. A. and Van Herwaarden, A. F. (2005 b). Agronomic evaluation of a tiller inhibition gene (tin) in wheat. II. Growth and partitioning of assimilate. Australian Journal of Agriculture Research, 56, 179-186. https://doi.org/10.1071/AR04153

Fioreze, S. L. and Rodrigues, J. D. (2012). Perfilhamento do trigo em função da aplicação de regulador vegetal. Revista Brasileira de Ciências Agrárias, 7, 750-755. https://doi.org/10.5039/agraria.v7isa1923

Fioreze, S. L., Vacari, J., Turek, T. L., Michelon, L. H. and Drun, R. P. (2019). Componentes produtivos do trigo em função da temperatura no período de diferenciação de espiguetas. Revista de Ciências Agroveterinárias, 18, 24-32. https://doi.org/10.5965/223811711812019024

Ferreira, D. F. (2011). Sisvar: a computer statistical analysis system. Ciência e Agrotecnologia, 35, 1039-1042. https://doi.org/10.1590/ S1413-70542011000600001

Gross, T. F., Dias, A. R., Kappes, C., Schiebelbein, L. M., Anselmo, J. L. and Holanda, H. V. (2012). Productive performance of wheat in different sowing methods and densities. Scientia Agrária Paranaensis, 11, 50-60. https://doi.org/10.18188/1983-1471/sap.v11n4p50-60

Guo, Z. and Schnurbusch, T. (2015). Variation of floret fertility in hexaploid wheat revealed by tiller removal. Journal of Experimental Botany, 66, 5945-5958. https://doi.org/10.1093/jxb/erv303

Hendriks, P. W., Kirkegaard, J. A., Lilley, J. M., Gregory, P. J. and Rebetzke, G. J. (2016). A tillering inhibition gene influences root-shoot carbon partitioning and pattern of water use to improve wheat productivity in rainfed environments. Journal of Experimental Botany, 67 , 327-340. https://doi.org/10.1093/jxb/erv457

Houshmandfar, A., Rebetzke, G. J., Lawes, R. and Tausz, M. (2019). Grain yield responsiveness to water supply in near-isogenic reducedtillering wheat lines - An engineered crop trait near its upper limit. European Journal of Agronomy, 102, 33-38. https://doi.org/10.1016/j. eja.2018.11.003

Inoue, T., Inanaga, S., Sugimoto, Y. and El Siddig, K. (2004). Contribution of preanthesis assimilates and current photosynthesis to grain yield, and their relationships to drought resistance in wheat cultivars grown under different soil moisture. Photosynthetica, $42,99-104$. https://doi.org/10.1023/B:PHOT.0000040576.52128.ed

Kebrom, T. H., Chandler, P. M., Swain, S. M., King, R. W., Richards, R. A. and Spielmeyer, W. (2012). Inhibition of tiller bud outgrowth in the tin mutant of wheat is associated with precocious internode development. Plant Physiology, 160, 308-318. https://doi.org/10.1104/ pp.112.197954

Masle, J. (1984). Competition among tillers in winter wheat: consequences for growth and development of the crops. In: NATO Advanced Research Workshop on Wheat Growth and Modelling (p. 33-54). Bristol. New York: Plenum. https://doi.org/10.1007/978-1-4899-3665-3 4

Mitchell, J. H., Rebetzke, G. J., Chapman, S. C. and Fukai, S. (2013). Evaluation of reduced-tillering (tin) wheat lines in managed, terminal water deficit environment. Journal of Experimental Botany, 64, 3439-3451. https://doi.org/10.1093/jxb/ert181 
Ruan, Y., Hu, Y. and Schmidhalter, U. (2012). Effect of tiller removal on ion content in main stem and subtillers of spring wheat under moderate salinity. Journal of Plant Nutrition, 35, 1314-1328. https://doi.org/10.1080/01904167.2012.684124

Shao, L., Zhang, X., Hideki, A., Tsuji, W. and Chen, S. (2010). Effects of defoliation on grain yield and water use of winter wheat. The Journal of Agricultural Science, 148, 191-204. https://doi.org/10.1017/S0021859609990542

Thapa, S., Reddy, S. K., Fuentealba, M. P., Xue, Q., Rudd, J. C., Jessup, K. E., Devkota, R. N. and Liu, S. (2017). Physiological responses to water stress and yield of winter wheat cultivars differing in drought tolerance. Journal of Agronomy and Crop Science, 204, $347-358$. https://doi.org/10.1111/jac.12263

Turek, T. L., Michelonm L. H., Tochetto, C., Coelho, A. E. and Fioreze, S. L. (2018). Consumo de água e eficiência produtiva de plantas de trigo tratadas com Etil-trinexapac. Revista de Ciências Agroveterinárias, 17, 198-205. https://doi.org/10.5965/223811711722018198

Vesohoski, F., Marchioro, V. S., Franco, F. A. and Cantelle, A. (2011). Components of grain yield in wheat and its direct and indirect effects on productivity. Revista Ceres, 58, 337-341. https://doi.org/10.1590/S0034-737X2011000300014

Zadoks, J. C., Chang, T. T. and Konzak, C. F. (1974). A decimal code for the growth stages of cereals. Weed Research, 14, 415-421. https:// doi.org/10.1111/j.1365-3180.1974.tb01084.x 